\title{
Water level changes of high altitude lakes in Himalaya-Karakoram from ICESat altimetry
}

\author{
Priyeshu Srivastava $^{1,2}$, Rakesh Bhambri ${ }^{1, *}$, Prashant Kawishwar ${ }^{3}$ and D P Dobhal ${ }^{1}$ \\ ${ }^{1}$ Centre for Glaciology, Wadia Institute of Himalayan Geology, 33 GMS Road, Dehradun 248 001, India. \\ ${ }^{2}$ Department of Geology, University of Pune, Pune 411 007, India. \\ ${ }^{3}$ Chhattisgarh Council of Science and Technology, MIG-25, Indrawati Colony, Raipur 492 001, India. \\ *Corresponding author. e-mail: rakeshbhambri@gmail.com
}

Himalaya-Karakoram $(\mathrm{H}-\mathrm{K})$ region hosts large number of high altitude lakes but are poorly gauged by in-situ water level monitoring method due to tough terrain conditions and poor accessibility. After the campaigns of ICESat during 2003-2009, now it is possible to achieve lake levels at decimetre accuracy. Therefore, in present study, high altitude lake levels were observed using ICESat/GLAS altimetry in $\mathrm{H}-\mathrm{K}$ between 2003 and 2009 to generate baseline information. The study reveals that out of 13 lakes, 10 lakes show increasing trend of water levels at different rate (mean rate $0.173 \mathrm{~m} / \mathrm{y}$ ) whereas three lakes unveiled decreasing trend (mean rate $-0.056 \mathrm{~m} / \mathrm{y}$ ). Out of five freshwater lakes, four lakes show an increasing trend of their level (mean rate $0.084 \mathrm{~m} / \mathrm{y}$ ) whereas comparatively six salt lakes (out of seven salt lakes) exhibited $\sim 3$ times higher mean rate of lake level increase $(0.233 \mathrm{~m} / \mathrm{y})$. These observed lake level rise can be attributed to the increased melt runoffs (i.e., seasonal snow and glacier melts) owing to the enhanced mean annual and seasonal air temperature during past decade in north-western (NW) Himalaya. Further, varied behaviours of lake level rises in inter- and intra-basins suggest that the local climatic fluctuations play prominent role along with regional and global climate in complex geographical system of NW Himalaya.

\section{Introduction}

The Himalayan Mountain Range has experienced changes in temperature and precipitation during recent decades due to the rise in greenhouse gas concentrations (IPCC 2007; Ramanathan et al. 2007; Ramanathan and Feng 2009; UNEP 2009; Singh et al. 2011). Water melts from the Himalayan glaciers and seasonal snow packs are one of the water sources for high altitude wetlands and lakes (Xu et al. 2009) and to Himalayan rivers (Immerzeel et al. 2010). Several studies have assessed the status of glaciers in the Himalaya (Berthier et al. 2007; Bhambri and Bolch 2009; Bhambri et al. 2011; Fujita and Nuimura 2011;
Bolch et al. 2012; Kääb et al. 2012) and their potential impacts over water availability (Immerzeel et al. 2010), biodiversity and ecosystem boundary shifts (Xu et al. 2009). However, relatively few studies of water level fluctuations of high altitude lakes of the surrounding of Hindu KushKarakoram-Himalaya (HKKH) have been conducted (e.g., Tibetan Plateau by Li et al. 2007; Zhang et al. 2011; Phan et al. 2012; Wang et al. 2013).

The high altitude lakes are sensitive to the changes in air temperature, precipitation, snowglacier melt and soil frost degradation (Gibson et al. 2006; Liu et al. 2009). Lake systems also reflect the water mass balance or hydrological

Keywords. ICESat/GLAS; lake level; Himalaya-Karakoram; remote sensing. 
cycle of their basin. As a result lake level variations are considered as significant indicators of climate change. High altitude lake level fluctuations influence their biodiversity, as well as that of the surroundings, the dissolved sediment profile and mineral characteristics. In addition, reduced lake levels could have significant ecological consequences as they are refugia for wildlife and play prominent role in the socio-economics of the region (Panigrahy et al. 2011). A recent study has shown that glacial lake areas have shrunk in the midlatitude westerlies-dominated Karakoram region; in the central Himalayan region, lake areas have slightly increased; and in the Indian-monsoon dominated eastern Himalaya the lakes have expanded in the last few decades (Gardelle et al. 2011). Individual glacier lake area increase has also been reported in Bhutan (Fujita et al. 2008; Komori 2008) and in Nepal Himalaya (Fujita et al. 2009) and also in Indian Himalaya (Kulkarni 1996; Babu Govindha Raj 2010).

The quantitative lake water level changes are still poorly available using hydrological gauge measurements due to the harsh weather conditions in remote and rugged Himalaya-Karakoram. Furthermore, due to economic and geopolitical reasons, limited spatial distribution of hydrological gauges is often the limitation to availability of adequate or constant observations. Advanced remote sensing techniques offer great potential to monitor the lakes water level in these remote mountain areas.
Previous studies have used satellite radar and laser altimetry methods, including Topex/Poseidon with accuracy of a few centimeters to obtain water level changes in lakes (Mercier et al. 2002; Hwang et al. 2011); ENVISAT Radar Altimeter (Medina et al. 2008); and ICESat/GLAS Altimeter (Zhang et al. 2011; Phan et al. 2012; Wang et al. 2013). Recently, Phan et al. (2012) reported lake level changes of Tibetan lakes including three lakes in Ladakh Himalaya and Aksai Chin (Pangong Tso, Pangur Tso and Aqsayqin Hu lakes) using ICESat/GLAS data. However, there are no studies addressing lake level changes for the larger region of the $\mathrm{H}-\mathrm{K}$. Thus the main goals of this study are: (1) to generate a baseline database for high altitude lake level changes in $\mathrm{H}-\mathrm{K}$ region using ICESat/GLAS data, (2) to estimate volume gain or loss of the lakes during the study period, and (3) to discuss the possible impact of climate variables on lake level changes.

\section{Study area}

The $\mathrm{H}-\mathrm{K}$ (figure 1) comprises of one of the largest collections of glaciers outside the polar regions, with a total glacier cover of over $47,000 \mathrm{~km}^{2}$ (Bolch et al. 2012) and is home to thousands of lakes and wetlands (Gujja et al. 2003). The study area is influenced by three climate patterns as categorized by precipitation regime: (1) Westerlies-dominated

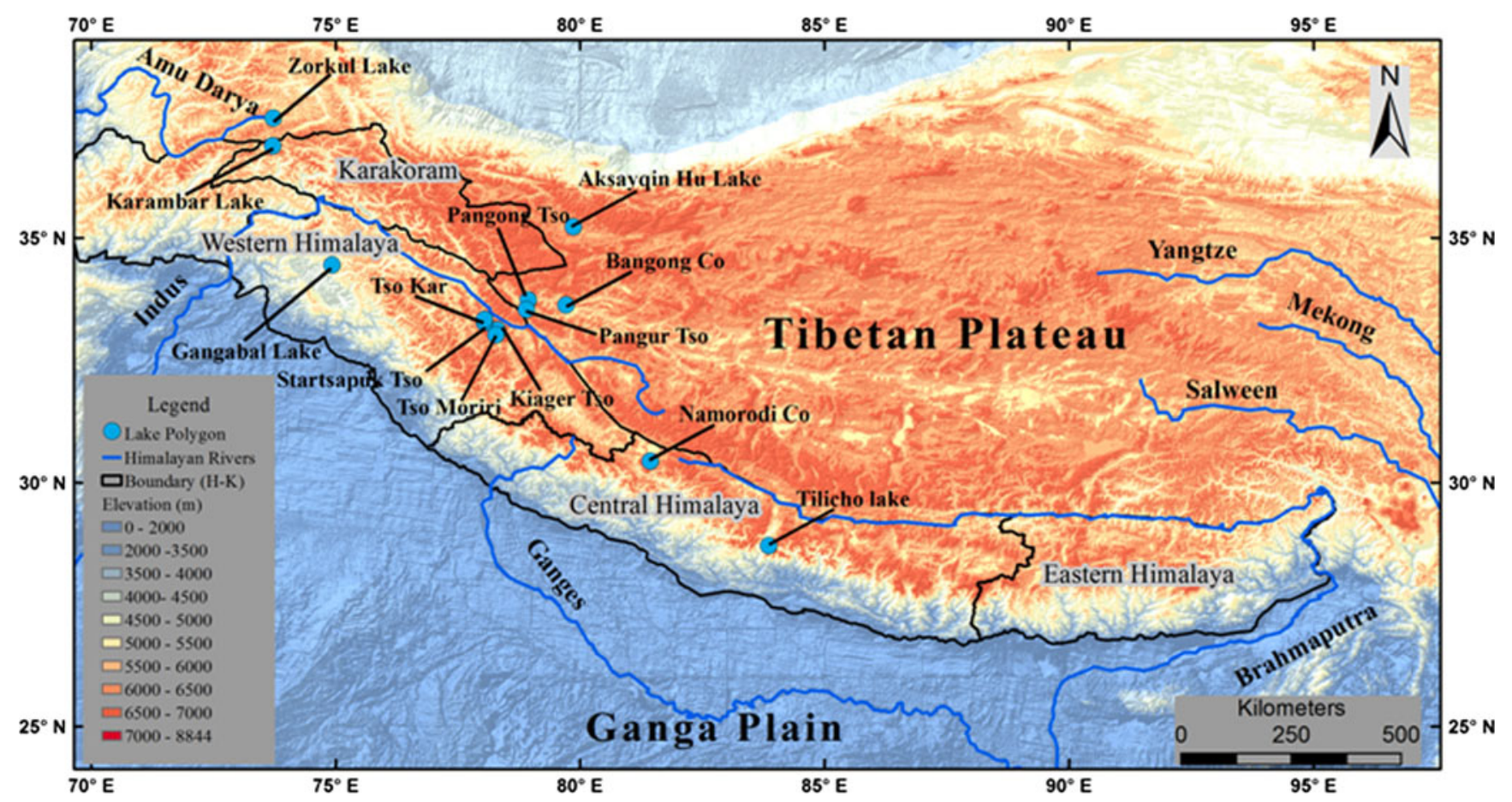

Figure 1. Location map of Himalaya-Karakoram $(\mathrm{H}-\mathrm{K})$ showing studied high altitude lakes (blue circles) with major river systems (background - SRTM $1 \mathrm{~km}$ spatial resolution). 
NW Himalaya-Karakoram; (2) Westerlies and Indian-monsoon influenced central Himalaya and (3) Indian-monsoon dominated eastern Himalaya. The study sites (figure 1 marked with blue circles) are mainly located in the Westerlies-dominated NW Himalaya-Karakoram.

\section{Methodology}

\subsection{ICESat/GLAS}

The Ice Cloud and Land Elevation Satellite (ICESat) carrying the Geoscience Laser Altimeter System (GLAS) was launched on 13 January 2003 (Zwally et al. 2002; Schutz et al. 2005). GLAS provides elevation data between $86^{\circ} \mathrm{N}$ and $86^{\circ} \mathrm{S}$ latitude with $\sim 65 \mathrm{~m}$ footprint at $172 \mathrm{~m}$ intervals along the earth's surface (Schutz et al. 2005). The main objective of the ICESat mission was to determine inter-annual and long-term changes in polar ice sheets with an accuracy of more than $2 \mathrm{~cm} /$ year (Schutz et al. 2005). Kwok et al. (2004) measured $\sim 2 \mathrm{~cm}$ accuracy over relatively flat sea ice. Recently, Zhang et al. (2011) also reported vertical accuracy of $\sim 2 \mathrm{~cm}$ for ICESat data for high altitude lake level monitoring on the Tibetan plateau and validated those results using geodetic GPS measurements at a hydrological gauge station.

The GLAS provides global land elevation data in two products GLA06 and GLA14. The GLA06 data contains adequate surface elevations of nonvegetated and smooth terrain (Urban et al. 2008) and GLA14 is commonly used for rough terrain surfaces (Nuth and Kääb 2011). Nuth and Kääb (2011) further discussed the suitability of GLA06 data for ice analysis. The high altitude lakes in the Himalaya-Karakoram fall mostly in ice-frozen regions during winter seasons. Therefore taking into account the significant accuracy background and suitability for the present study, ICESat/GLAS-L1B Global Elevation Data (GLA06), V031 data release were obtained for years 2003 to 2009 from U.S. National Snow and Ice Data Centre (www.nsidc.org).

\subsection{Lake outlines}

Due to unavailability of any detailed high altitude lake inventory, we used two datasets to make our own inventory: 'Shuttle Radar Topography Mission' (SRTM) Water Body Dataset (SWBD) and 'Moderate-Resolution Imaging Spectro-radiometer' (MODIS) water mask data (Carroll et al. 2009). SWBD data at $90 \mathrm{~m}$ resolution was acquired from United States Geological Survey (USGS; http://dds.cr.usgs.gov/ srtm/version2_1/SWBD/) for the entire study area. MODIS water mask data were obtained from Global Land Cover Facility (GLCF; ftp://ftp.glcf. umd.edu/modis/WaterMask/Collection_5/2000) at $250 \mathrm{~m}$ resolution as recommended by Phan et al. (2012). The MODIS snow cover products (500 m pixel size), provide lake water as one class (Hall et al. 2002) and is of coarser resolution, therefore this data was not used in the present study. The SWBD vector outlines are relatively smoother than the MODIS water mask owing to their higher resolution and we concentrated on those outline. A total of 709 water bodies (including rivers, lakes and man-made dams) were identified from SWBD outlines for study area. These polygons derived from the SWBD outlines were evaluated using Google Earth and available Landsat TM images to eliminate rivers and seasonal lakes.

A total of 74 US Army Map Service (AMS) topography maps were used to assimilate information related to lakes including name, nature of lake (fresh or salt water lakes) and their spatial location in different mountain ranges and subsequently were included in our Geographic Information System (GIS) database.

\subsection{ICESat/GLAS data processing, filtering and outliers extraction}

There were 1533 ICESat/GLAS laser ranging data granules or tracks within our study area. The NSIDC's GLAS Altimetry elevation extractor tool (NGAT; http://nsidc.org/data/icesat/tools.html) was used to extract point elevation data (as well as metadata such as the date of acquisition, latitude and longitude). ArcGIS software was used to generate vector shape file. The ICESat tracks in shape files were intersected with SWBD outline polygon shape file to extract water bodies having ICESat tracks.

Further, a set of data filters were applied to extract natural high altitude lakes having sufficient number of ICESat tracks with large numbers of elevation measurement-points (postings). Table 1 summarizes the detailed filtering criteria applied for selection of high altitude natural lakes with total and remaining number of water bodies after extraction. After filtering of water bodies only 13 high altitude natural lakes were found suitable for study of altimetry changes.

ICESat tracks over all 13 natural lakes were then processed for outlier extraction using methods suggested by Zhang et al. (2011): (1) by visual inspection of each ICESat track's elevation profile and (2) calculation of the standard deviation (STD) of the remaining data and elimination of those data with high standard deviation. Zhang et al. (2011) suggested two threshold 
Table 1. Applied data filtering steps for selection of natural high altitude lakes for altimetry change study.

\begin{tabular}{|c|c|c|c|}
\hline $\begin{array}{l}\text { Filter } \\
\text { steps }\end{array}$ & $\begin{array}{c}\text { No. of } \\
\text { water bodies } \\
\text { (before filtering) }\end{array}$ & $\begin{array}{c}\text { No. of } \\
\text { water bodies } \\
\text { (after filtering) }\end{array}$ & $\begin{array}{l}\text { Criteria for } \\
\text { filtering }\end{array}$ \\
\hline 1 & 709 & 85 & $\begin{array}{l}\text { Extraction of water bodies } \\
\text { having no ICESat tracks path. }\end{array}$ \\
\hline 2 & 85 & 28 & $\begin{array}{l}\text { Extraction of water bodies } \\
\text { having very less }(<3) \text { ICESat } \\
\text { tracks path and footprints or } \\
\text { data for less time span }(<3) \text { years. }\end{array}$ \\
\hline 3 & 28 & 20 & Extraction of river water bodies. \\
\hline 4 & 20 & 13 & Extraction of man-made water reservoirs \\
\hline
\end{tabular}

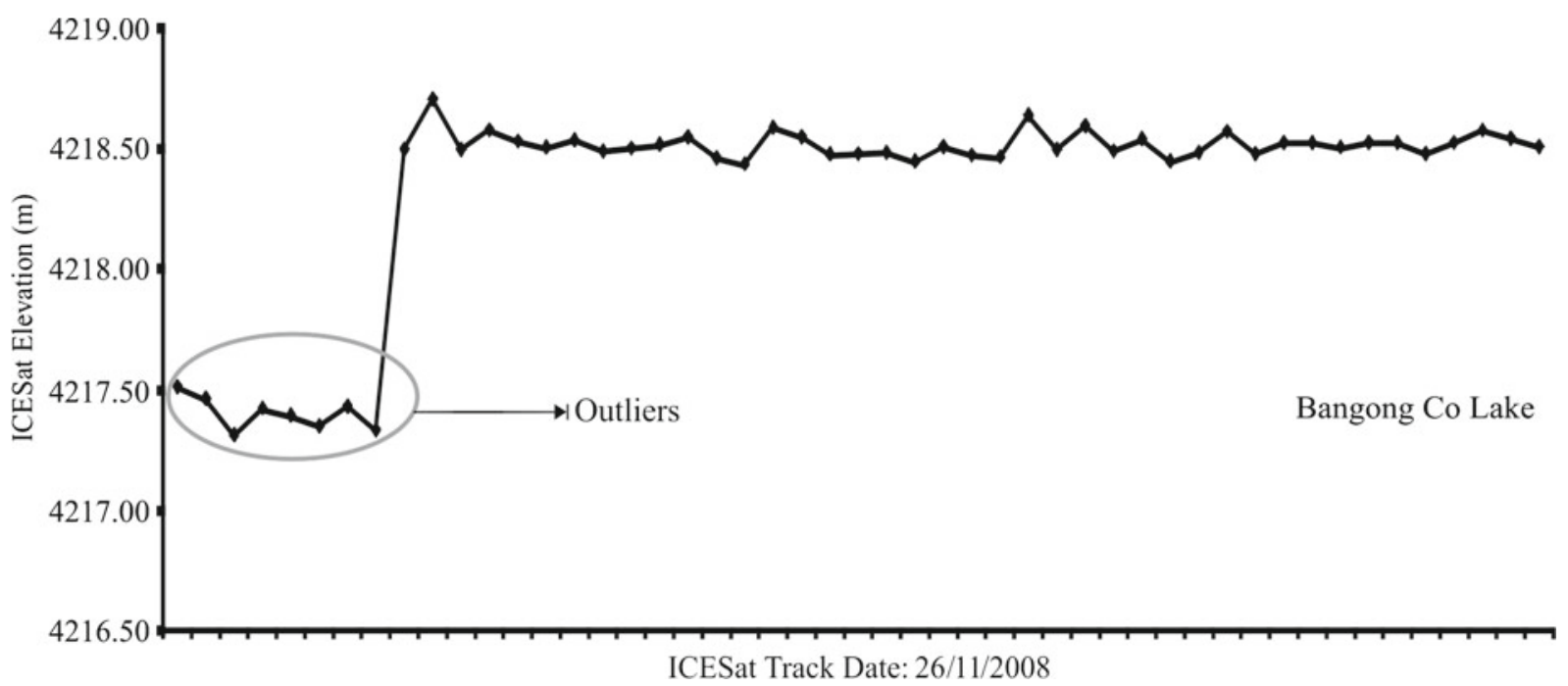

Figure 2. Average elevation plot of ICESat track path (26/11/2008) over Bangong Co Lake showing eight footprints producing an abnormal high standard deviation presented here as outliers (circled).

STD values to eliminate outliers from ICESat data: (1) $10 \mathrm{~cm}$ for water surface over lakes and (2) $30 \mathrm{~cm}$ for ice surface over frozen lakes. The difference in threshold values is due to the difference in surface roughness of water and ice. However, in the present study we used the higher STD threshold because lack of field observations prevents us from determining the proper value from ground-truth data. Therefore, the threshold value of $30 \mathrm{~cm}$ was used to determine outliers of measured elevation of each ICESat track was applied for all seasons. For example, ICESat track path on 26/11/2008 over Bangong Co lake (figure 2) showed 08 footprints (circled, in total 49 footprints), which brings out an abnormal high STD of $0.42 \mathrm{~m}$ while after elimination of these 08 footprints, STD was reduced to $0.05 \mathrm{~m}$.

\subsection{Lake level and volume change estimation}

The observed water level change of a lake $(\Delta e)$ was calculated based on subtraction of lake surface elevation of the latest data ('end date' elevation $e_{e}$, generally in 2009) from the earliest measured elevation ('start date' $\boldsymbol{e}_{s}$, generally in 2003) of a given repeated ICESat track.

$$
\Delta e=\left[e_{e}-e_{s}\right]
$$

In addition, estimated elevation change of a lake $\left(\Delta e_{r}\right)$ was calculated using rate of change (de) and applying that for the observation period $N$ (in years):

$$
\Delta e_{r}=[d e * N]
$$


where rate of change (de) was calculated based on linear regression analysis as suggested by Zhang et al. (2011).

Volume change of lakes $(\Delta V)$ was also estimated:

$$
\Delta V=A * \Delta e
$$

where area $A$ is measured from SWBD outlines and considered here as constant during study period (2003-2009).

\section{Results}

After data filtering and outlier extraction, altimetry data of all 13 lakes were statistically computed (table 2). The mean footprints per track over the lakes varied between 4 and 67 and the number of tracks for all observed years were in the range of 3 to 44 . This variability is due to the large spacing of the satellite paths in non-polar regions, and the relatively small size of the lakes. Mean STD values based on effective/edited footprints were found to vary between 0.04 and $0.15 \mathrm{~m}$ with an average of $0.12 \mathrm{~m}$. The observed rate of change also indicates a significant variation from -0.119 to $0.462 \mathrm{~m} / \mathrm{y}$.

\subsection{Lake level change analysis based on lake type}

The studied lakes were categorized into fresh and salt water lakes based on available literature. Out of all 13 lakes, seven were categorized as salt lakes and five as freshwater lakes and one lake was uncategorized, since no classification was found in literature (table 2).

Six salt lakes show an increasing lake level trend with a mean rate of $0.233 \mathrm{~m} / \mathrm{y}$, while one salt lake (Tso Moriri) shows decrease in lake levels with $-0.119 \mathrm{~m} / \mathrm{y}$ rate of change. A similar trend of lake level change was also observed for freshwater lakes but with a different rate. Four freshwater lakes show an increasing water level trend with a mean rate of $0.084 \mathrm{~m} / \mathrm{y}$, whereas one freshwater lake (Tilicho lake) represents decreasing trend with $-0.01 \mathrm{~m} / \mathrm{y}$. The uncategorized lake also shows decrease in lake level with $-0.038 \mathrm{~m} / \mathrm{y}$ rate of change. Mean rate of increasing water level for salt lakes was $0.233 \mathrm{~m} / \mathrm{y}$ which is considerably a very high rate ( $\sim$ three fold) as comparative to freshwater lake level increasing rate $(0.084 \mathrm{~m} / \mathrm{y})$.

\subsection{Lake level change analysis based on spatial location}

In order to examine whether lake change behaviour varies across the $\mathrm{H}-\mathrm{K}$, the 13 lakes have been categorized into four regions based on their spatial locations: (1) NW H-K region, (2) central

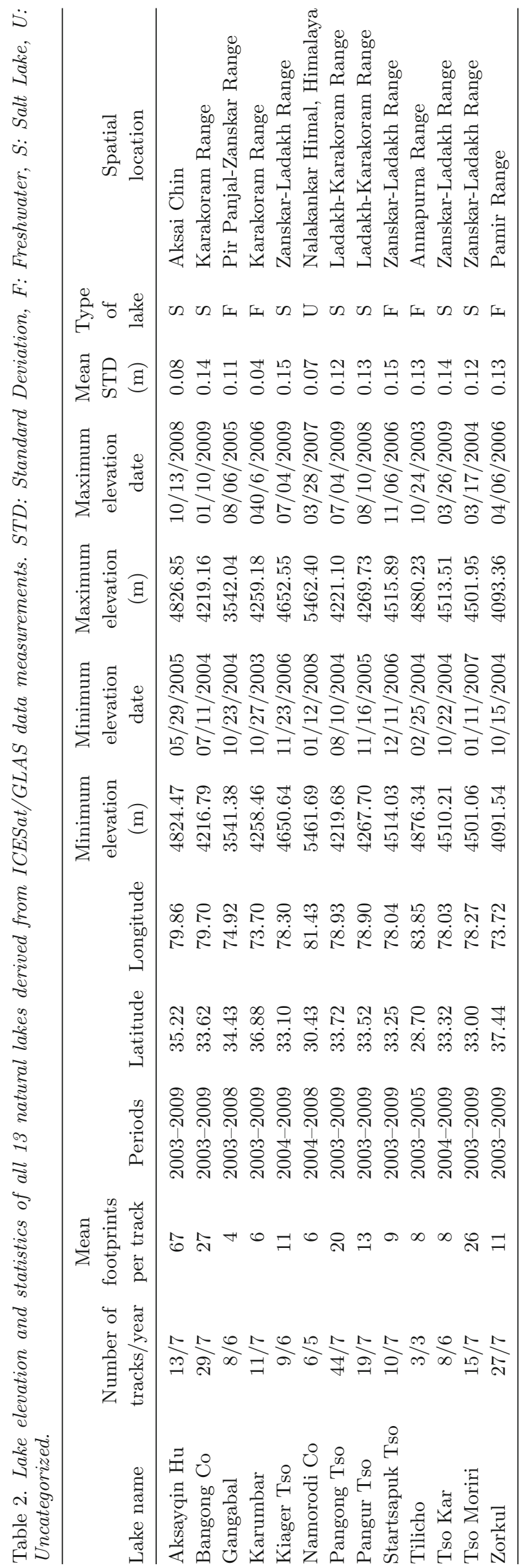


Himalaya, (3) Pamir ranges and (4) Aksai Chin plateau.

(1) In north-western $\mathrm{H}-\mathrm{K}$ region from south to north: (a) Pir Panjal-Zanskar mountain range contains only Gangabal lake (fresh water), in which water is rising at negligible rate of $0.009 \mathrm{~m} / \mathrm{y}$; (b) Zanskar-Ladakh range has four lakes in which three lakes' level is rising at a high mean rate of $0.279 \mathrm{~m} / \mathrm{y}$ while the lake level of one lake is lowering at $-0.119 \mathrm{~m} / \mathrm{y}$ rate; (c) farther in the Ladakh-Karakoram range, two lakes are rising at $0.094 \mathrm{~m} / \mathrm{y}$ mean rate of change and other two lakes in the Karakoram range are rising at $0.086 \mathrm{~m} / \mathrm{y}$ mean rate of change.

(2) In central Himalayan range, two lakes (Namorodi Co and Tilicho lake) in the Nalakankar Himal and Annapurna range, respectively, show decreasing lake level trend with $-0.038 \mathrm{~m} / \mathrm{y}$ and $-0.01 \mathrm{~m} / \mathrm{y}$.

(3) In Pamir range, Zorkul lake shows a small rate of rise at $0.064 \mathrm{~m} / \mathrm{y}$ and

(4) Aksayqin Hu lake (Aksai Chin plateau) has a high rate of change of $0.462 \mathrm{~m} / \mathrm{y}$.

\subsection{Lake volume change}

Water volume change of a lake depends on the area and elevation change of the lake. The estimated water volume of eight lakes had significant increase whereas five lakes had a decrease during the study period (2003-2009) (table 3). The Aksayqin $\mathrm{Hu}$ and Tso Moriri lakes (both salt lakes) show maximum increase $\left(0.69 \mathrm{~km}^{3}\right)$ and decrease $\left(-0.17 \mathrm{~km}^{3}\right)$ in their water volume, respectively. Volume change estimation based on fixed area provides the first approximation of volume gain or loss (Phan et al. 2012); therefore present study of the volume change of lake gives preliminary results of lake volume gain or loss.

\section{Discussion}

\subsection{Lake level changes using remote sensing}

The observed relation between rate of change $(d e)$ and volume change $(\Delta V)$ does not work for Bangong $\mathrm{Co}$ and Gangabal lakes. These two lakes show a decrease in volume change $(\Delta V)$ while increasing rate of change $(d e)$ is found (table 3 ). The estimated elevation change $\left(\Delta e_{r}\right)$ shows increase whereas observed water level change $(\Delta e)$ shows a decrease in both lake levels. This suggests a minor overestimation of rate of change from linear regression method for both lakes and

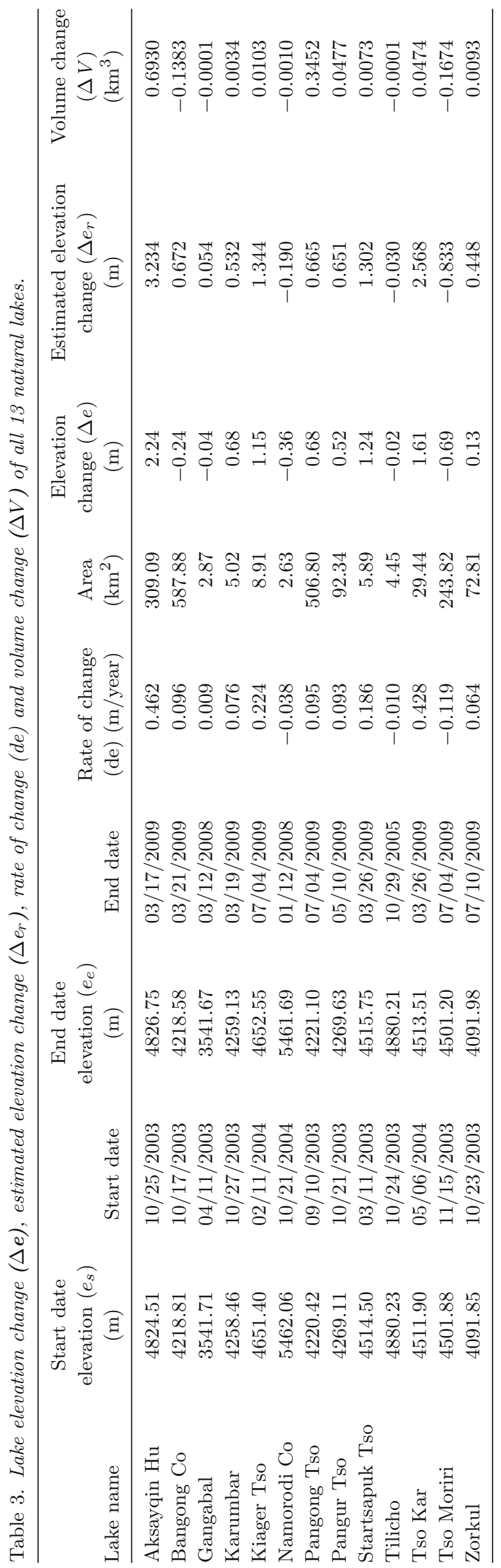


could be credited to the high year-to-year variability. However these two lakes (Bangong Co and Gangabal) have a low net change (indistinguishable from zero), so we are not overly concerned by this discrepancy.

Phan et al. (2012) reported rate of change for the Pangong Tso, Pangur Tso and Aqsayqin Hu lakes based on GLA14 datasets and different thresholds criteria used for elimination of outliers. Our findings for rate of change $(0.095 ; 0.093$ and $0.462 \mathrm{~m} / \mathrm{y})$ (using STD threshold of $30 \mathrm{~cm}$ ) well accords with Phan et al. (2012) findings of 0.098; 0.092 and $0.504 \mathrm{~m} / \mathrm{y}$ (STD threshold of $35 \mathrm{~cm}$ ) for abovedescribed three lakes, i.e., Pangong Tso, Pangur Tso and Aqsayqin $\mathrm{Hu}$, respectively. This suggests that the use of GLA06 datasets is also well suitable for lake level monitoring studies.

In a regional assessment and mapping (using IRS P6 LISS III with spatial resolution of $24 \mathrm{~m}$ ) of high altitudinal lakes $(>3000 \mathrm{~m})$ in Indian Himalaya, a total of 4703 lakes were reported with only 42 lakes larger than $1 \mathrm{~km}^{2}$ (Panigrahy et al. 2011). The above study suggests the presence of higher number of small lakes in the rugged undulated mountain topography of $\mathrm{H}-\mathrm{K}$ comparative to large lakes in more or less flat Tibetan plateau (Zhang et al. 2011; Wang et al. 2013). In most cases, ICESat track does not pass over lakes and sometimes due to smaller size of lakes less number of ICESat tracks and footprints are available. High cloud cover over $\mathrm{H}-\mathrm{K}$ region is also one of the reasons for loss of footprints and less number of ICESat tracks. The ICESat data obtained from 2003 to 2006 on an average represent 268 ICESat tracks per year, whereas in 2007 to 2008, 185 ICESat tracks per year and only 116 ICESat tracks in 2009. These sets of GLA06 show a relatively less number of ICESat tracks in the successive years. The small number of ICESat tracks found over the study area, limits the comprehensive quantitative regional assessment of climate change impact. Therefore, path coverage of the planned ICESat mission-2 (Abdalati et al. 2010) over the $\mathrm{H}-\mathrm{K}$ region and Tibet should be considered in this context.

\subsection{Lake level and climatic variations}

Out of 13 lakes studied, two lakes are located in central Himalaya while rest of 11 lakes is situated into westerlies-dominated NW HimalayaKarakoram region (figure 1). The two lakes of central Himalayan region (Tilicho and Namorodi Co lakes) are lowering at -0.01 and $-0.038 \mathrm{~m} / \mathrm{y}$ respectively during study period. Both lakes are too small [Tilicho $\left(4.45 \mathrm{~km}^{2}\right)$ and Namorodi Co $\left.\left(2.63 \mathrm{~km}^{2}\right)\right]$ in their area and are not representative to make a comment on lake level change characteristics of the entire central Himalaya. The NW Himalaya-Karakoram region has 11 lakes falling into different mountain ranges with different climatic variables. Out of these, 10 lakes are rising with $0.173 \mathrm{~m} / \mathrm{y}$ mean rate of change, whereas one lake (Tso Moriri) shows decreasing trend of the lake levels with $-0.119 \mathrm{~m} / \mathrm{y}$ (figure 3 ).

The lake level changes in different mountain ranges of NW Himalaya-Karakoram region (see result section 4.2) is in concurrent with the findings of Shekhar et al. (2010) who reported significant rise in air temperature of these ranges with maximum at Greater Himalaya. Whereas decrease in mean summer and increase in maximum winter temperature is recorded for Karakoram range based on observational network (Fowler and Archer 2006). However, decreasing trend in seasonal snowfall is recorded for all NW Himalayan mountain ranges with maximum decrease over Greater Himalaya and minimum (negligible) at eastern Karakoram range (Shekhar et al. 2010) and contrastingly increased annual precipitation is reported in Upper Indus Basin of western Karakoram range (Archer and Fowler 2004). This suggests that increased air temperatures would have resulted in enhanced seasonal snow and glacier melt and consequently resulting in increased melt runoff to NW Himalayan lakes during past decade. For rising lake level in Karakoram range, increased annual precipitation (Archer and Fowler 2004) appears to be the primary reason of increased water sources to lakes, whereas decreased temperature would have also indirectly contributed to the rise in lake level by reducing evaporation rate. However, it is to be noted that the previous climatic studies have adopted different methodologies to analyze metrological data and gives a generalized idea of temperature and precipitation conditions in different mountain ranges.

Salt lakes can be used as a proxy for integrated climate change (Mason et al. 1991, 1994) in high altitudes. For instance, two inter-basin lakes, Tso Kar (salt water) and Startsapuk Tso (freshwater) lakes (figure 4) respectively represent single closed drainage basin - Tso Kar, surrounded by ZanskarLadakh range. The water recharge resources to these lakes are mainly from adjacent glaciers, snow melt and from the rivers Pulong-Kha-Phu from the east (only seasonally active) and the perennial river Nuruchan Lungpa from the south (Philip and Mazari 2000). Both rivers feed freshwater to Startsapuk Tso lake while the saline Tso Kar is fed by water exchange via a small conduit connecting both lakes. Our results indicate that Tso Kar lake is rising at the rate of $0.428 \mathrm{~m} / \mathrm{y}$ which is more than twice the rate of change for Startsapuk Tso lake $(0.186 \mathrm{~m} / \mathrm{y})$. The difference in rate of increasing 

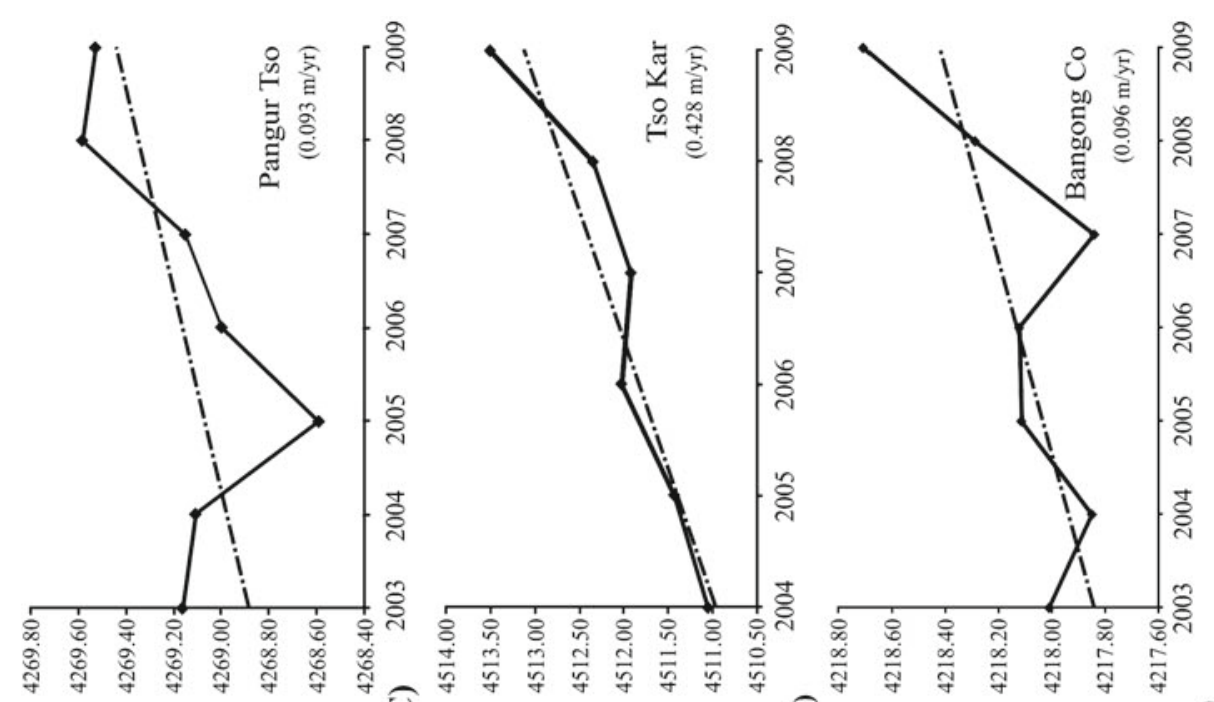

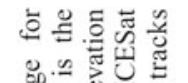

픙 吅

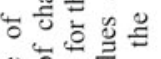

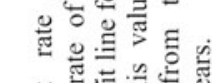

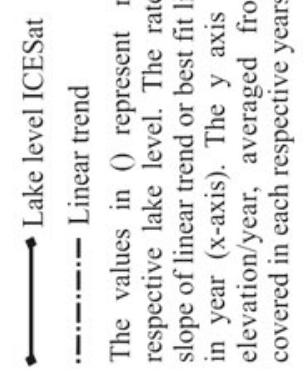

豙
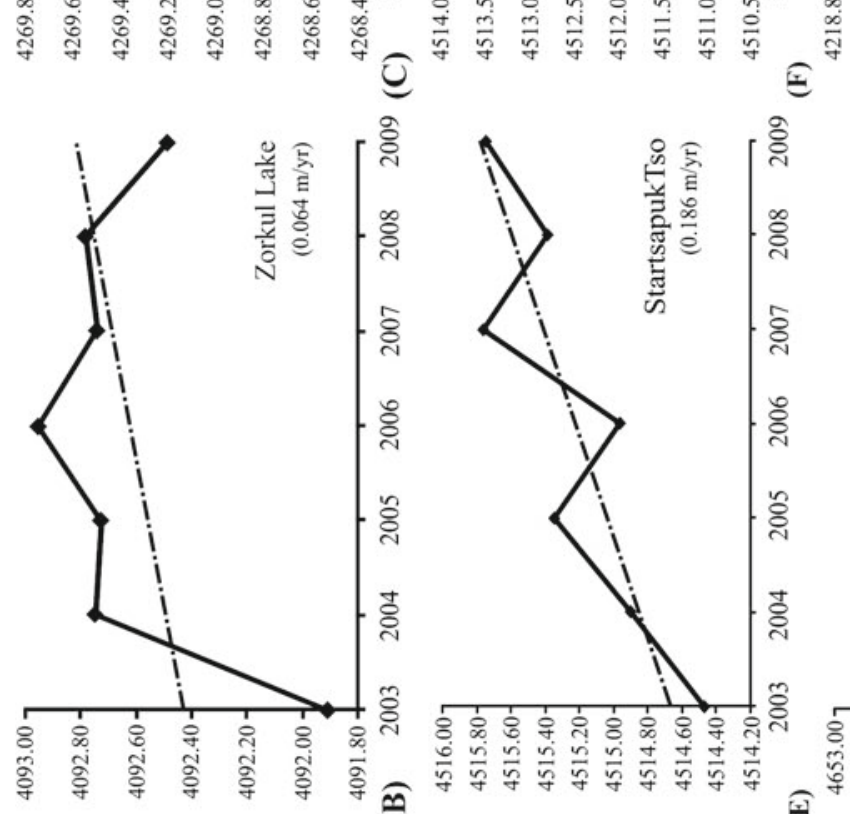

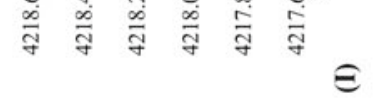

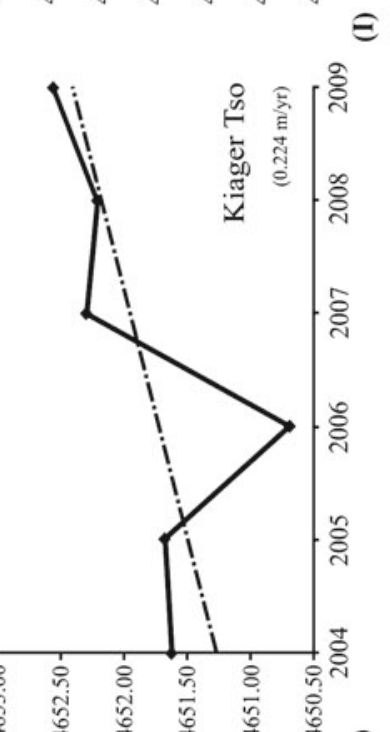

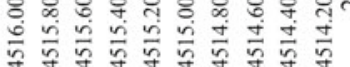

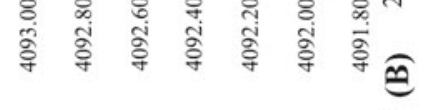

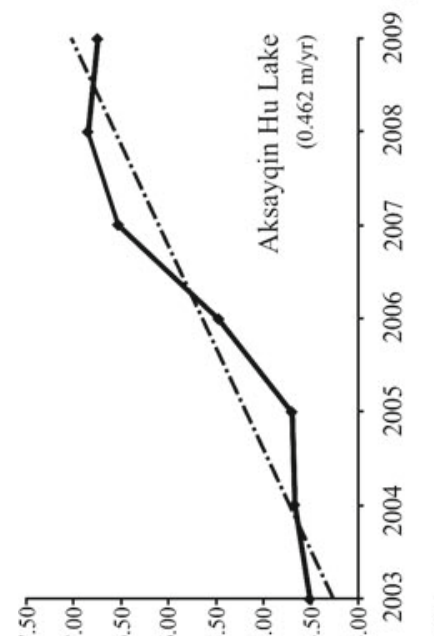

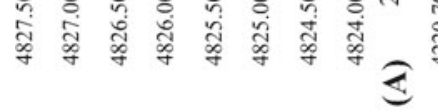

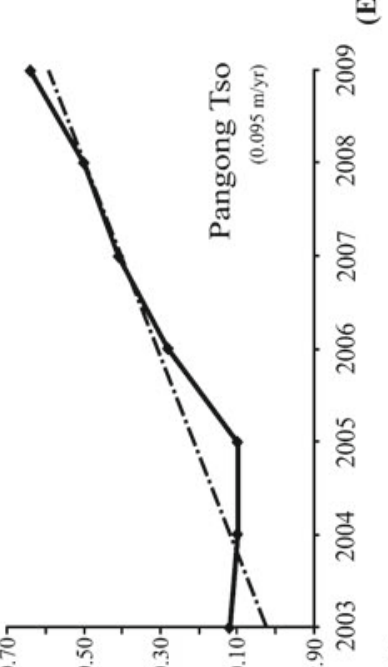

실

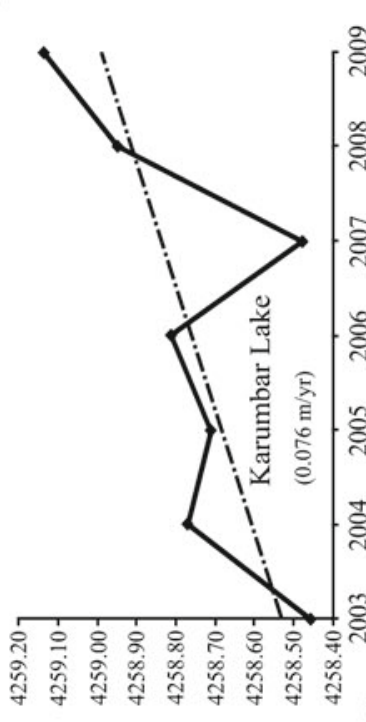

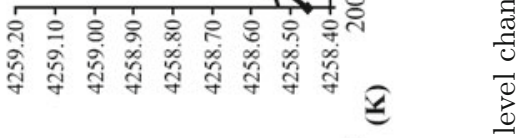
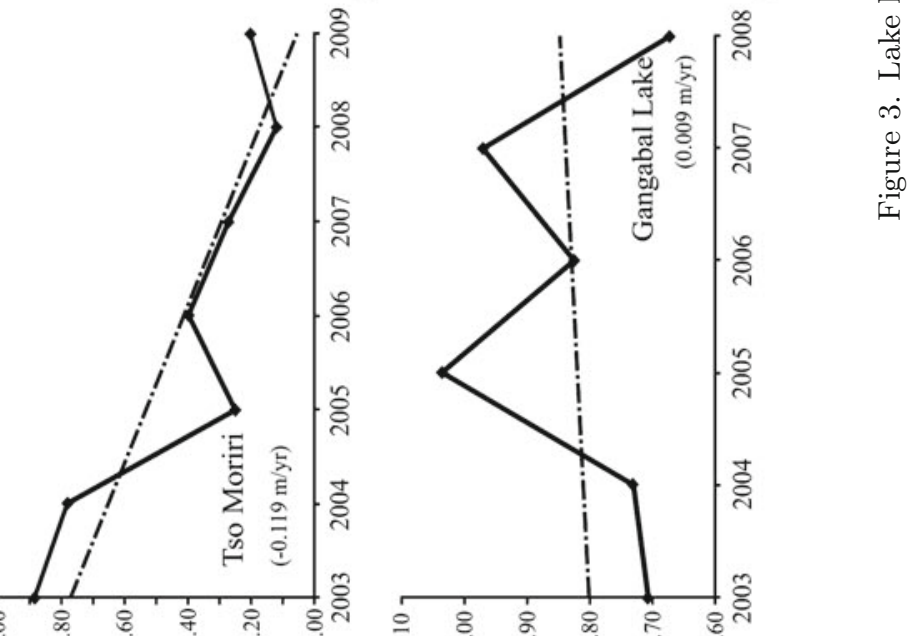


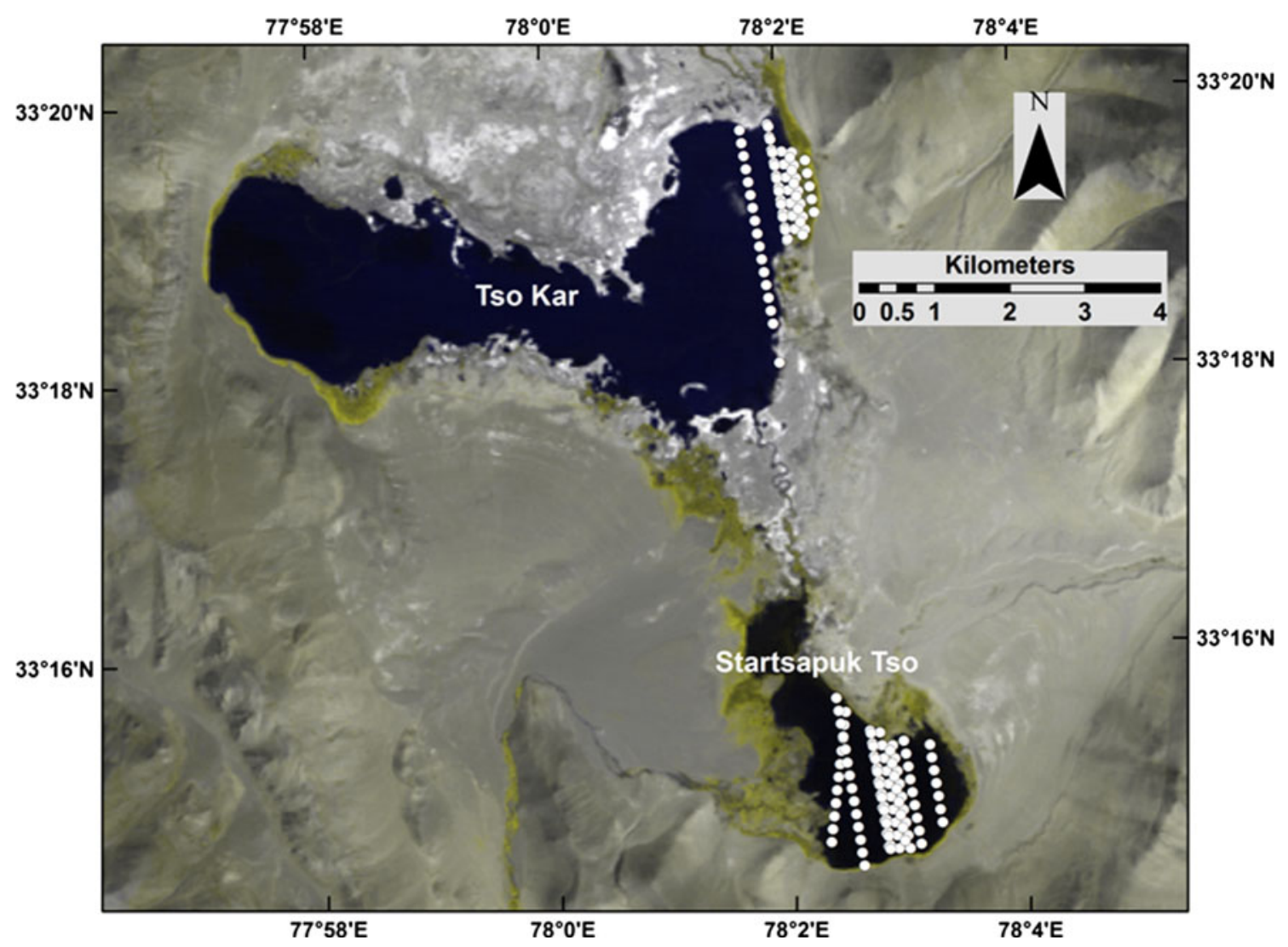

Figure 4. A visual representation of ICESat track path with white circles (2003-2009) over Tso Kar and Startsapuk Tso lakes [background presented by 4-4-3 band combination of Landsat TM imagery (20-09-2011)].

lake levels of both lakes can be attributed to the loss of water from Startsapuk Tso lake (freshwater) by evaporation and stream water drainage to Tso Kar whereas evaporation is only source for loss of water from Tso Kar lake. This may also be the case for other studied freshwater lakes. Therefore this further affirms that salt lakes make more reliable gauges of climatic variations (specifically precipitation and glacier/seasonal snow melt changes).

Next, we compare two neighbouring intra-basin lakes, Tso Moriri and Kiager Tso (both salt lakes) of Zanskar-Ladakh range, which are experiencing opposing trends. The lake level of Kiager Tso is rising at the rate of $0.224 \mathrm{~m} / \mathrm{y}$; while for Tso Moriri, lake level is falling at the rate of $-0.119 \mathrm{~m} / \mathrm{y}$ during the study period. The rising lake level of Kiager Tso is consistent with other lakes of the NW Himalaya-Karakoram region and is interpreted for the similar reasons. Whereas the decreased lake level of the Tso Moriri is in agreement with the findings of Lesher (2011) who reported decrease in lake area during 2000 to 2009 owing to increased evaporation and shorter ice free days over lake basin. This indicates understanding of climate change and lake level variability in high altitudes of NW Himalaya requires detailed ground-based hydrological monitoring system.

\section{Conclusions}

Our inventory of 13 high altitude lake level change for the period 2003-2009 using ICESat/GLAS data will not only provide the first time base line information but heterogeneous lake levels will also be valuable to a number of disciplines such as lake ecosystems and lake-management practices. The present study demonstrates that the lakes of NW Himalaya show significant fluctuations in lake level from 2003 to 2009. The maximum rise in the lake level was observed for the Zanskar-Ladakh range by a mean rate of $0.279 \mathrm{~m} / \mathrm{y}$. The increased lake levels accords with the increased temperature over NW Himalaya which seems to be the key source for the lake level rise as the increased seasonal snow and glacier melt will enhance the contribution of the melt runoffs to lakes. The temperature rise plays the contrasting behaviours for lake level variability: (1) enhanced seasonal snow and glacier melt will directly contribute to lake level rise and (2) increased evaporation will lower lake level as observed for Tso Moriri lake. The observed heterogeneous behaviour of lake level rises and decrease in inter- and intra-basins suggest that the local climate fluctuations are also controlling component along the regional and global climate in complex 
geographical system of NW Himalaya. The small number of ICESat tracks limits the number of studied lakes but could be used for monitoring the larger lakes. However a detailed study of meteorology and water balance budget of lakes is still needed to find the contributions of different meteorological elements (i.e., temperature, precipitation and evaporation) to these lake level changes.

\section{Acknowledgements}

The authors thank the Director, Wadia Institute of Himalayan Geology, Dehradun and Director General, Chhattisgarh Council of Science and Technology, Raipur for their support for this work. Priyeshu Srivastava thanks Prof. Sridhar Anandakrishnan of Penn State University, USA for his insightful comments and suggestion on earlier version of manuscript. Rakesh Bhambri thanks Eero Rinne of School of Geosciences, University of Edinburgh, UK for extracting ICESat tracks in shape files. They also thank U.S. National Snow and Ice Data Centre (NSIDC) for providing GLAS/ICESat altimetry data at no cost.

\section{References}

Abdalati W, Zwally H J, Bindschadler R, Csatho B, Farrell S L, Fricker H A, Harding D, Kwok R, Lefsky M, Markus T, Marshak A, Neumann T, Palm S, Schutz B, Smith B, Spinhirne J and Webb C 2010 The ICESat-2 Laser Altimetry Mission; Proc. IEEE 98 735-751.

Archer D R and Fowler H J 2004 Spatial and temporal variations in precipitation in the Upper Indus Basin, global teleconnections and hydrological implications; Hydrol. Earth Syst. Sci. 8 47-61.

Babu Govindha Raj K 2010 Remote sensing based hazard assessment of glacial lakes: A case study in Zanskar basin, Jammu and Kashmir, India; Geomatics, Natural Hazards and Risk $1339-347$.

Berthier E, Arnaud Y, Kumar R, Ahmad S, Wagnon P and Chevallier P 2007 Remote sensing estimates of glacier mass balances in the Himachal Pradesh (Western Himalayas, India); Remote Sens. Environ. 108 327-338.

Bhambri R and Bolch T 2009 Glacier mapping: A review with special reference to the Indian Himalayas; Progr. Phys. Geogr. 33 672-704.

Bhambri R, Bolch T, Chaujar R K and Kulshreshtha S C 2011 Glacier changes in the Garhwal Himalayas, India 1968-2006 based on remote sensing; J. Glaciol. 57 $543-556$.

Bolch T, Kulkarni A, Kääb A, Huggel C, Paul F, Cogley G, Frey H, Kargel J, Fujita K, Scheel M, Stoffel M and Samjwal B 2012 The state and fate of Himalayan glaciers; Science 336 310-314.

Carroll M L, Townshend J R, DiMiceli C M, Noojipady P and Sohlberg R A 2009 A new global raster water mask at $250 \mathrm{~m}$ resolution; Int. J. Digital Earth 2 291-308.

Fowler H J and Archer D R 2006 Conflicting signals of climatic change in the Upper Indus Basin; J. Climate 19 4276-4293.
Fujita K and Nuimura T 2011 Spatially heterogeneous wastage of Himalayan glaciers; PNAS 108 14,011-14,014.

Fujita K, Suzuki R, Nuimura T and Sakai A 2008 Performance of ASTER and SRTM DEMs, and their potential for assessing glacial lakes in the Lunana region, Bhutan Himalaya; J. Glaciol. 54 220-228.

Fujita K, Sakai A, Nuimura T, Yamaguchi S and Sharma R 2009 Recent changes in Imja Glacial Lake and its damming moraine in the Nepal Himalaya revealed by in situ surveys and multi-temporal ASTER imagery; Environ. Res. Lett. 4 1-7.

Gardelle J, Arnaud Y and Berthier E 2011 Contrasted evolution of glacial lakes along the Hindu Kush Himalaya mountain range between 1990 and 2009; Global Planet. Change $\mathbf{7 5} 47-55$.

Gibson J J, Prowse T D and Peters D L 2006 Hydroclimatic controls on water balance and water level variability in Great Slave Lake; J. Hydrol. Process. 20 4155-4172.

Gujja B, Chatterjee A, Gautam P and Chandan P 2003 Wetlands and lakes at the top of the world; Mt. Res. Dev. 23 219-221.

Hall D K, Riggs G A, Salomonson V V, DiGirolamo N E and Bayr K J 2002 MODIS snow-cover products; Remote Sens. Environ. 83 181-194.

Hwang C, Kao Y C and Tangdamrongsub N 2011 A preliminary analysis of lake level and water storage changes over lakes Baikal and Balkhash from satellite altimetry and gravimetry; Terr. Atmos. Ocean Sci. 22 97-108.

Immerzeel W W, Van Beek L P H and Bierkens M F P 2010 Climate change will affect the Asian water towers; Science 328 1382-1385.

IPCC 2007 Climate Change 2007: Synthesis Reported Core Writing Team (eds) Pachauri R K and Reisinger A (Geneva: IPCC).

Kääb A, Berthier E, Nuth C, Gardelle J and Arnaud Y 2012 Contrasting patterns of early twenty-first-century glacier mass change in the Himalayas; Nature 488 495-498.

Komori J 2008 Recent expansions of glacial lakes in the Bhutan Himalayas; Quat. Int. 184 177-186.

Kulkarni A V 1996 Moraine-dammed glacial lake studies using remote sensing technique; Him. Geol. 17 161-164.

Kwok R, Zwally H J and Yi D 2004 ICESat observations of Arctic sea ice: A first look; Geophys. Res. Lett. L16401 31 1-5.

Lesher S R 2011 Climate change impacts to a high altitude lake in the Indian Himalaya; Disseration Thesis, San Diego State University.

Li X Y, Xu H Y, Sun Y L, Zhang D S and Yang Z P 2007 Lake-level change and water balance analysis at Lake Qinghai, west China during recent decades; Water Resourc. Manag. 21 1505-1516.

Liu J, Wang S, Yu S, Yang D and Zhang L 2009 Climate warming and growth of high elevation inland lakes on the Tibetan Plateau; Global Planet. Change $\mathbf{6 7}$ 209-217.

Mason I M, Guzkowska M A J, Rapley C G and StreetPerrot F A 1994 The response of lake levels and areas to climatic change; Clim. Change 27 161-197.

Mason I M, Harris A R, Birkett C M, Cudlip W and Rapley C E 1991 Remote sensing of lakes for the proxy monitoring of climatic change; Proc. 16th Ann. Conf. Remote Sensing Society, pp. 314-324.

Medina C, Gomez E J, Alonso J J and Villares P 2008 Water level fluctuations derived from ENVISAT Radar Altimeter (RA-2) and in-situ measurements in a subtropical water body: Lake Izabal (Guatemala); Remote Sens. Environ. 112 3604-3617. 
Mercier F, Cazenave A and Maheu C 2002 Interannual lake level fluctuations (1993-1999) in Africa from Topex/Poseidon: Connections with ocean-atmosphere interactions over the Indian Ocean; Global Planet. Change 32 141-163.

Nuth C and Kääb A 2011 Co-registration and bias corrections of satellite elevation data sets for quantifying glacier thickness change; The Cryosphere $\mathbf{5}$ 271-290.

Panigrahy S, Patel J G, Singh T S and Murthy T V R 2011 National Wetland Inventory and Assessment: High Altitude Himalayan Lakes; SAC/ESPA/NWIA/IN/03/2010, pp. 1-20.

Phan V H, Lindenbergh R and Menenti M 2012 ICESat derived elevation changes of Tibetan lakes between 2003 and 2009; Int. J. Appl. Earth Observ. Geoinf. 17 $12-22$.

Philip G and Mazari R K 2000 Shrinking lake basins in the proximity of the Indus Suture Zone of northwestern Himalaya: A case study of Tso Kar and Startsapuk Tso, using IRS-1C data; Int. J. Remote Sens. 21 2973-2984.

Ramanathan V and Feng Y 2009 Air pollution, greenhouse gases and climate change: Global and regional perspectives; Atmos. Environ. 43 37-50.

Ramanathan V, Ramana M V, Roberts G, Kim D, Corrigan C, Chung C and Winker D 2007 Warming trends in Asia amplified by brown clouds solar absorption; Nature 448 575-578.

Schutz B E, Zwally H J, Shuman C A, Hancock D and DiMarzio J P 2005 Overview of the ICESat mission; Geophys. Res. Lett. L21S01 32 1-5.
Shekhar M, Chand H, Kumar S, Srinivasan K and Ganju A 2010 Climate-change studies in the Western Himalaya; Ann. Glaciol. 51 105-112.

Singh S P, Bassignana-Khadka I, Karky B S and Sharma E 2011 Climate change in the Hindu Kush-Himalayas: The state of current knowledge; Kathmandu: ICIMOD.

UNEP 2009 Recent Trends in Melting Glaciers, Tropospheric Temperatures over the Himalayas and Summer Monsoon Rainfall over India (Nairobi: United Nations Environment Programme).

Urban T J, Schutz B E and Neuenschwander A L 2008 A survey of ICESat coastal altimetry applications: Continental coast, open ocean island, and inland river; Terr. Atmos. Oceanic Sci. 19 1-19.

Wang X, Gong P, Zhao Y, Xu Y, Cheng X, Niu Z, Luo Z, Huang H, Sun F and Li X 2013 Water-level changes in China's large lakes determined from ICESat/GLAS data; Remote Sens. Environ. 132 131-144.

Xu J, Grumbine E, Shrestha A, Eriksson M, Yang X, Wang Y and Wilkes A 2009 The melting Himalayas: Cascading effects of climate change on water, biodiversity, and livelihoods; Conserv. Biol. 235 20-30.

Zhang G, Xie H, Kang S, Yi D and Ackley S F 2011 Monitoring lake level changes on the Tibetan Plateau using ICESat altimetry data (2003-2009); Remote Sens. Environ. 115 1733-1742.

Zwally H J, Schutz B, Abdalati W, Abshire J, Bentley C, Brenner A, Bufton J, Dezio J, Hancock D, Harding D, Herring T, Minster B, Quinn K, Palm S, Spinhirne J and Thomas R 2002 ICESat's laser measurements of polar ice, atmosphere, ocean, and land; J. Geodyn. 34 405-445. 